\title{
COMMUNITY KNOWLEDGE ABOUT POSKESTREN \\ AS A COMMUNITY BASED HEALTH INITIATIVE \\ AT DARUSSALAM AL-FAISHOLIYAH ISLAMIC \\ BOARDING SCHOOL, SAMPANG, MADURA
}

\author{
Marselli Widya Lestari, Wiwik Winarningsih
}

Department of Public Health, Faculty of Medicine, Universitas Nahdlatul Ulama Surabaya

\begin{abstract}
Background: In boarding schools, students don't have their parents around to watch them at all time. Parents want to make sure that their children are making sensible decision about health, nutrition, and exercise. Islamic Boarding School presents facilities to maintain and increase the health of the students. This study aimed to investigate community knowledge about Islamic Boarding School Health Post (Poskestren) as a community based health initiative at Darussalam Al-Faisholiyah Islamic Boarding School, Sampang, Madura.

Subjects and Method: This was qualitative study conducted at Darussalam Al-Faisholiyah Islamic Boarding School, Sampang, Madura. A sample of informants including students, stakeholders, dan community around Islamic Boarding School, was selected or this study. The data were collected by in-depth interview and described accordingly.

Result: Most informants knew Poskestren (61.1\%). There were only $41.8 \%$ of informants were able to describe the abbreviation of Poskestren. $38.1 \%$ of informants misperceived about Poskestren as a community-based health initiative.

Conclusion: Most informants recognize Poskestren, but some informants misperceived about Poskestren as community based health initiative. Professionals have yet to explain more about Poskestren, so that the aim of the community based health initiative is attainable.
\end{abstract}

Keywords: Islamic Boarding School Health Post, knowledge, community-based health initiative

\section{Correspondence:}

Marselli Widya Lestari. Department of Public Health, Faculty of Medicine, Universitas Nahdlatul Ulama Surabaya. Jl. Jemursari 51-57, Surabaya, Indonesia. Email: marselliwidya@gmail.com. Mobile: 081703341579.

The $6^{\text {th }}$ International Conference on Public Health Best Western Premier Hotel, Solo, Indonesia, October 23-24, 2019 | 116 